\title{
Pelaksanaan Program BIPA dan Hasil Pembelajarannya
}

\author{
Kurniawan*), Devi Ambarwati P., Didiek Hardadi Batubara, Hernina, Larasati \\ Pusat Pengembangan Strategi dan Diplomasi Kebahasaan \\ *) Correspondences author: Jalan Anyar, KM. 4. Desa Tangkil, Citeureup, Bogor, 16910, Indonesia; \\ e-mail: kurniawan1984@kemdikbud.go.id
}

\begin{abstract}
The present study identified the learning outcomes of the program of Indonesian for foreigners (BIPA-Bahasa Indonesia untuk Penutur Asing) and the suitability between student learning outcomes and teaching materials of BIPA. The learning process of BIPA was conducted to improve four language competencies including listening, speaking, reading, and writing. Based on the 2016 and 2017 BIPA teaching reports, thirteen teachers assigned to teach BIPA to Thailand, Vietnam, Myanmar, France, and Russia were successfully able to improve the four language competencies of the students. Meanwhile, the suitability between student learning outcomes and teaching materials of BIPA indicated that: 1) sixty seven BIPA teachers were considered good at adjusting the learning to the teaching materials, 2) four BIPA teachers were rated fair in adjusting the learning to the teaching materials, and 3) ten BIPA teachers were considered poor in adjusting the learning to the teaching materials.
\end{abstract}

Key Words: BIPA; learning outcomes; teaching materials.

This work is licensed under a Creative Commons Attribution-ShareAlike 4.0 International License

\section{Pendahuluan}

Seiring dengan kemajuan yang telah dicapai oleh bangsa Indonesia di tengah era global sekarang ini, peran Indonesia dalam pergaulan antarbangsa juga telah menempatkan bahasa Indonesia sebagai salah satu bahasa yang dipandang penting di dunia. Hal itu juga ditunjang oleh posisi Indonesia dalam percaturan dunia yang semakin hari semakin penting, terutama melalui peranannya, baik dalam turut serta menyelesaikan konflik-konflik politik di berbagai kawasan maupun karena posisi geografis Indonesia yang terletak dalam lintas laut yang sangat strategis. Kenyataan seperti itu telah menyebabkan banyak orang asing yang tertarik dan berminat untuk mempelajari bahasa Indonesia sebagai alat untuk mencapai berbagai tujuan, baik tujuan politik, perdagangan, seni-budaya, maupun wisata.

Terkait dengan hal tersebut, bahasa Indonesia hingga saat ini telah diajarkan kepada orang asing di berbagai lembaga, baik di dalam maupun di luar negeri. Di dalam negeri saat ini tercatat tidak kurang dari 45 lembaga yang telah mengajarkan bahasa Indonesia bagi penutur asing (BIPA), baik di perguruan tinggi maupun di lembaga-lembaga kursus. Sementara itu, di luar negeri, Pengajaran BIPA telah dilakukan oleh sekitar 36 negara di dunia dengan jumlah lembaga tidak kurang dari 130 buah, yang terdiri atas perguruan tinggi, pusat-pusat kebudayaan asing, KBRI, dan lembaga-lembaga kursus. (Badan Pengembangan dan Pembinaan Bahasa, 2018)

Selama ini Pengajaran BIPA di lembaga-lembaga tersebut, baik di dalam maupun di luar negeri, dikelola dan dikembangkan oleh lembaga masing-masing tanpa ada lembaga induk yang memayungi lembaga-lembaga pengajar BIPA tersebut. Atas dasar itu, Badan Pengembangan dan Pembinaan Bahasa, Kementerian Pendidikan dan Kebudayaan Republik Indonesia sebagai lembaga pemerintah yang bertugas menangani masalah kebahasaan di Indonesia - merasa terpanggil dan bertanggung jawab untuk membina, mengembangkan, dan sekaligus memfasilitasi lembaga-lembaga tersebut agar masing-masing dapat hidup dan berkembang sesuai dengan karakteristiknya sendiri. Hal itu dimaksudkan agar pengajaran BIPA, baik di dalam maupun di luar negeri, terus tumbuh dan berkembang sehingga pada akhirnya bahasa Indonesia dapat menjadi bahasa pergaulan antarbangsa.

Pusat Pengembangan Strategi dan Diplomasi Kebahasaan (PPSDK) telah melaksanakan program BIPA sejak tahun 2015 sesuai dengan amanat UU Nomor 24 Tahun 2009 tentang Bendera, Bahasa, dan Lambang Negara, serta Lagu Kebanggsaan dan PP Nomor 57 Tahun 2014 tentang Pengembangan, 
Pembinaan, dan Pelindungan Bahasa dan Sastra, serta yujuan strategis Badan Bahasa 2015 - 2019, yaitu Peningkatan Jati Diri Bangsa melalui bahasa Indonesia serta pemakaian bahasa sebagai sarana pencerdasan bangsa. Untuk keperluan pengukuran ketercapaian tujuan strategis tersebut diperlukan sasaran strategis yang menggambarkan kondisi yang harus dicapai pada tahun 2019. Sasaran strategis Badan Bahasa tersebut antara lain: 1) meningkatnya mutu bahasa dan pemakaiannya sebagai penghela ipteks dan penguat daya saing Indonesia, 2) meningkatnya peran bahasa Indonesia sebagai bahasa perhubungan di kawasan ASEAN. Selain itu, program BIPA terselenggara karena besarnya minat penutur asing untuk mempelajari Bahasa Indonesia, baik dari negara-negara seperti Australia, Asia, Amerika, maupun Eropa. Selain itu, sudah banyak sekolah di luar negeri yang menerapkan kurikulum bahasa Indonesia sebagai bahasa asing pilihan. Salah satu contohnya adalah Universitas Sydney di Australia yang sudah sejak tahun 1973 menggalang kerja sama dalam penyelenggaraan program pengajaran bahasa Indonesia.

Jumlah peserta BIPA dari tahun ke tahun selalu meningkat. Para peserta program BIPA pun sangat bervariasi, terdiri dari siswa sekolah menengah, mahasiswa, pegawai pemerintah, swasta, maupun warga dari negara itu yang sudah pensiun. Meningkatnya minat penutur asing yang ingin belajar bahasa Indonesia ini telah mendorong munculnya kebutuhan terhadap program pengajaran yang harus ditangani secara profesional.

Berdasarkan laporan-laporan yang telah dibuat oleh tenaga-tenaga pengajar BIPA yang telah dikirimkan oleh PPSDK, menunjukkan bahwa pemelajar bahasa Indonesia di luar negeri masih banyak mengalami kesulitan dalam mencapai tujuan pembelajaran. Banyak pengajar yang melaporkan hasil belajar siswa yang masih banyak terdapat kesalahan. Kesalahan-kesalahan berbahasa yang dibuat oleh penutur asing dominan berasal dari proses transfer dari bahasa Inggris ke dalam bahasa Indonesia, baik dalam hal pemilihan kata, struktur kalimat, ucapan, dan pemakaian imbuhan. Kesalahan-kesalahan tersebut menjadi perhatian tersendiri dalam pencapaian komptensi pemelajar.

Kajian strategis kebahasaan yang menyangkut hasil belajar pemelajar BIPA dan pencapaian kompetensi pemelajar BIPA belum banyak dilakukan. Oleh karena itu, dilakukan kajian program BIPA yang diselenggarakan pada tahun 2016 - 2017 yang secara umum bertujuan untuk mencapai target kinerja kajian strategis kebahasaan tahun 2018. Secara khusus, kajian dilakukan untuk mengetahui bagaimana hasil pembelajaran program BIPA dan kesesuaian antara hasil belajar siswa dengan bahan ajar BIPA yang dikembangkan oleh PPSDK. Berdasarkan kajian yang telah dilakukan, disusunlah laporan kajian BIPA: Hasil Pembelajaran dari Pelaksanaan Program BIPA tahun 2016 sampai dengan 2017. Penelitian ini bertujuan untuk memaparkan tentang kesesuaian antara hasil belajar siswa dengan Standar Kompetensi Lulusan BIPA. Selain itu, penelitian ini diharapkan dapat memberikan manfaat sebagai bahan pertimbangan untuk penyusunan kebijakan, yaitu kebijakan melaksanakan penyusunan pedoman pengembangan strategi kebahasaan dan kebijakan penyusunan pedoman diplomasi kebahasaan.

Pada bulan Mei 2016, jalur pendidikan nonformal tercatat sekitar 19.692 lembaga kursus dan pelatihan yang menyelenggarakan pendidikan nonformal dalam bentuk beragam jenis kursus dan pelatihan di bawah pembinaan Kementerian Pendidikan dan Kebudayaan. Salah satu infrastruktur yang penting dalam mencapai keselarasan mutu dan penjenjangan kualifikasi antara lulusan dari institusi penyelenggara kursus dan pelatihan dengan deskripsi kompetensi kerja yang diharapkan oleh pengguna lulusan adalah dokumen Standar Kompetensi Lulusan disingkat SKL, sebagaimana dinyatakan pada Peraturan Pemerintah Nomor 13 Tahun 2015 tentang Perubahan Kedua Atas Peraturan Pemerintah Nomor 19 Tahun 2005 tentang Standar Nasional Pendidikan dalam hal penyusunan suatu SKL, dan Permendikbud Nomor 131 Tahun 2014 dan Permendikbud Nomor 5 Tahun 2016 tentang Standar Kompetensi Lulusan Kursus dan Pelatihan.

Dengan terbitnya Peraturan Presiden Nomor 8 Tahun 2012 tentang Kerangka Kualifikasi Nasional Indonesia, maka SKL kursus dan pelatihan disusun berbasis KKNI untuk mengakomodasi perubahan kebutuhan kompetensi kerja dari pengguna lulusan di dunia kerja dan dunia industry. Salah satu bidang yang mengembangkan Standar Kompetensi Lulusan ini adalah Bidang Bahasa Indonesia bagi Penutur Asing (BIPA). Ada perbedaan antara BIPA dengan bidang lainnya, yaitu peserta yang mengikuti kusus dan pelatihan ini. Peserta BIPA merupakan warga negara asing atau warga negara Indonesia yang tidak bisa berbahasa Indonesia. Peserta didik ini memelajari bahasa Indonesia untuk berbagai tujuan, di antaranya dapat berinteraksi dan berkomunikasi dengan menggunakan bahasa Indonesia, bukan untuk mendapatkan keahlian dalam bidang pekerjaan. 


\section{Metode}

Penelitian ini merupakan penelitian kuantitatif dengan menerapkan metode deskriptif. Penelitian deskriptif kuantitatif menekankan pada prosedur penelitian yang menghasilkan data berupa angka atau grafik hasil analisis dokumen-dokumen BIPA yang telah disusun oleh pengajar-pengajar BIPA yang telah selesai mengajar ke luar negeri. Dokumen-dokumen hasil pelaksanaan program BIPA dari rentang tahun 2016 sampai dengan 2017. Kuesioner merupakan data pendukung yang diambil peserta lokakarya pengajar BIPA yang sudah bertugas pada tahun 2016-2017 di berbagai negara. Metode yang digunakan untuk mengumpulkan data yakni metode studi pustaka. Studi pustaka dilakukan dengan mengumpulkan data sembari mengamati dan mempelajari BIPA maupun pembelajaran bahasa asing. Data tersebut berupa bukubuku literatur, artikel, jurnal, dan sumber bacaan lain yang dianggap relevan. Studi pustaka juga merupakan suatu langkah dalam proses penguatan pemahaman dan internalisasi makna akan berbagai hal yang terkait dalam proses penelitian. Selain itu, metode simak juga digunakan untuk memperoleh data. Berikut langkahlangkah dalam proses pengumpulan data:

1) Proses pengumpulan data dimulai dari proses transkripsi dengan mencatat seluruh hasil kegiatan pembelajaran BIPA yang telah dilaksanakan dari rentang tahun 2016 sampai dengan 2017.

2) Setelah melakukan proses transkripsi, data yang berupa hasil proses pembelajaran BIPA akan dipilih.

3) Data yang sudah dipilih kemudian diklasifikasikan kembali ke dalam beberapa pembagian kriteria hasil pembelajaran BIPA yang sesuai dengan maksud dan tujuannya.

4) Data yang sudah terbagi atas kriteria-kriteria yang ditentukan kemudian dihitung kuantitasnya dan dijabarkan secara deskriptif.

Analisis data kuantitatif dilakukan untuk mengonfirmasi data hasil kegiatan pengajaran BIPA berdasarkan kuantitas. Analisis data kuantitatif terdiri dari tiga proses kegiatan, yaitu reduksi data, penyajian data, dan penarikan kesimpulan. Tahap reduksi data dalam penelitian ini yaitu proses pemilihan data yang berupa hasil-hasil pembelajaran BIPA yang telah dilaksanakan oleh pemelajar BIPA. Data dipilih menggunakan teknik purposive sampling, yakni salah satu teknik sampling nonrandom sampling, yaitu peneliti menentukan pengambilan sampel dengan cara menetapkan ciri-ciri khusus yang sesuai dengan tujuan penelitian sehingga diharapkan dapat menjawab permasalahan penelitian. Setelah data diperoleh, maka akan dilakukan proses penghitungan kuantitas berdasarkan dari kategori-kategori yang telah ditetapkan sesuai dengan maksud dan tujuan kajian.

Penyajian data merupakan pendataan data yang telah diseleksi dan diklasifikasikan ke dalam jenis bentuk hasil-hasil pembelajaran. Analisis heuristik dan hermeneutik digunakan untuk menganalisis hasilhasil pembelajaran BIPA. Analisis heuristik adalah analisis pemberian makna berdasarkan struktur bahasa secara konvensional atau dianalisis dalam pengertian yang sesungguhnya dari maksud bahasa. Kerja heuristik menghasilkan pemahaman makna secara harfiah, makna tersurat, dan actual meaning. Analisis hermeneutik merupakan pembacaan bolak-balik terhadap teks dari awal hingga akhir. Tahap pembacaan ini merupakan interpretasi tahap kedua yang bersifat retroaktif yang melibatkan banyak kode di luar bahasa dan menggabungkannya secara integratif sampai pembaca dapat membongkar makna bacaan secara struktural guna mengungkapkan makna keseluruhan teks (Sumaryono, 1999).

Data yang sudah diklasifikasikan kedalam bentuk hasil pembelajaran dianalisis dengan menggunakan klasifikasi hasil dan kesesuaian dengan bahan ajar BIPA. Data yang telah dianalisis tersebut kemudian disajikan secara deskriptif kuantitatif, yakni dengan menerangkan kejelasan temuan-temuan melalui angka dan grafik. Data hasil studi pustaka dibandingkan dengan data hasil kuesioner sebelum dilakukan pnarikan kesimpulan.

Tahap analisis data kuantitatif yang terakhir adalah penarikan kesimpulan. Dalam kajian ini, kesimpulan dapat diambil selama proses analisis data dan diungkapkan dengan kalimat yang singkat, padat, dan mudah dipahami. Data yang sudah dianalisis, diklasifikasikan, diolah berdasarkan kuantitas, disajikan, selanjutnya dapat disimpulkan. 


\section{Hasil dan Pembahasan}

\section{Standar Kompetensi Lulusan BIPA}

Berdasarkan Permendikbud Nomor 27 Tahun 2017, penyusunan kompetensi lulusan (SKL) kursus dan pelatihan untuk bidang Bahasa Indonesia bagi Penutur Asing (BIPA) diadaptasi dari CEFR dan penjenjangan mengikuti penjenjangan dalam Uji Kemahiran Berbahasa Indonesia yang dikembangkan oleh Badan Pembinaan dan Pengembangan Bahasa. Alasannya adalah sebagai berikut.

Pertama, UKBI merupakan uji kemahiran berbahasa Indonesia yang terstandar yang dirilis oleh Badan Pengembangan dan Pembinaan Bahasa dan telah digunakan untuk menguji kemahiran berbahasa Indonesia, baik orang Indonesia maupun orang asing. Kedua, CEFR merupakan kerangka acuan bahasa asing di wilayah Eropa. Bahasa Indonesia dalam konteks kursus ini setara dengan bahasa Indonesia sebagai bahasa asing. Untuk itu, CEFR dianggap relevan untuk dijadikan rujukan dalam penentuan kompetensi setiap level dalam bidang bahasa. Dengan mengikuti kedua acuan tersebut dan diselaraskan dengan KKNI diharapkan identitas bahasa Indonesia tetap kuat dan bahasa Indonesia sebagai bahasa asing pun terakomodasi.

SKL BIPA disusun dengan tujuan untuk menjadi pedoman dalam merumuskan kurikulum, menentukan bahan pembelajaran, merencanakan dan melaksanakan pembelajaran, serta menentukan lulusan peserta didik pada lembaga kursus dan pelatihan, serta bagi yang belajar mandiri, sebagai acuan dalam menyusun, merevisi, atau memutakhirkan kurikulum, baik pada aspek perencanaan maupun implementasinya.

BIPA merupakan salah satu program pelatihan yang diperlukan dalam rangka peningkatkan fungsi bahasa negara sebagai bahasa internasional dan pemenuhan kebutuhan tenaga kerja asing akan program pelatihan bahasa Indonesia. Identifikasi kebutuhan pasar sangat diperlukan dalam persiapan kegiatan suatu program kursus atau pelatihan. Identifikasi kompetensi yang harus dimiliki oleh peserta didik BIPA juga diperlukan agar penyusunan standar kompetensi lulusan lebih terfokus.

Terdapat 7 level kompetensi yang di dalamnya meliputi empat kemahiran berbahasa, yaitu mendengarkan, berbicara, membaca, dan menulis. Program kursus dan pelatihan BIPA merupakan program kursus dan pelatihan untuk menghasilkan lulusan yang terampil berbahasa Indonesia untuk berbagai tujuan dalam berbagai konteks yang sesuai dengan kompetensi masing-masing level.

\section{Level Kemampuan Bahasa}

Untuk mengukur tingkat penguasaan bahasa seseorang diperlukan suatu tolok ukur yang jelas. Dalam fungsinya sebagai bahasa asing di berbagai negara, bahasa Indonesia menggunakan standar pelevelan SKL BIPA berdasarkan Permendikbud Nomor 27 Tahun 2017. SKL BIPA ini digunakan untuk memberikan keseragaman standar yang jelas dan objektif akan kemampuan berbahasa asing. Dalam standar ini terdapat 7 level atau tingkat kemampuan berbahasa. Berikut adalah penjelasan standar kompetensi yang harus dicapai pada masing-masing level.

Tabel 1. Parameter Deskripsi Capaian Pembelajaran Khusus Bidang Bahasa Indonesia Bagi Penutur Asing (BIPA) Level I

\begin{tabular}{|l|ll|}
\hline \multicolumn{2}{|c|}{ PARAMETER DESKRIPSI CAPAIAN PEMBELAJARAN KHUSUS BIDANG BAHASA INDONESIA BAGI PENUTUR } \\
ASING (BIPA) LEVEL I \\
\hline NIKAP DAN TATA & 1. & $\begin{array}{l}\text { Bertakwa kepada Tuhan Yang Maha Esa. } \\
\text { NILAI }\end{array}$ \\
2. & $\begin{array}{l}\text { Memiliki moral, etika hidup berkelanjutan dan kepribadian yang baik di dalam menyelesaikan } \\
\text { tugasnya. }\end{array}$ \\
3. & $\begin{array}{l}\text { Berperan sebagai warga negara yang bangga dan cinta tanah air serta mendukung perdamaian } \\
\text { dunia. } \\
\text { 4. }\end{array}$ \\
4. & $\begin{array}{l}\text { Mampu bekerja sama dan memiliki kepekaan sosial dan kepedulian yang tinggi terhadap } \\
\text { masyarakat dan lingkungan hidupnya. } \\
\text { Menghargai keanekaragaman budaya, pandangan, kepercayaan, dan agama serta } \\
\text { pendapat/temuan original orang lain. } \\
\text { Menjunjung tinggi penegakan hukum serta memiliki semangat untuk mendahulukan } \\
\text { kepentingan bangsa serta masyarakat luas. }\end{array}$ \\
\hline
\end{tabular}




\begin{tabular}{|c|c|}
\hline $\begin{array}{l}\text { CKEMAMPUAN DI } \\
\text { BIDANG KERJA }\end{array}$ & $\begin{array}{l}\text { Memahami dan menggunakan ungkapan konteks perkenalan diri dan pemenuhan kebutuhan konkret sehari- } \\
\text { hari dan rutin dengan cara sederhana untuk berkomunikasi dengan mitra tutur yang sangat kooperatif. }\end{array}$ \\
\hline $\begin{array}{l}\text { PENGETAHUAN } \\
\text { YANG DIKUASAI }\end{array}$ & $\begin{array}{l}\text { Menguasai penggunaan tata bahasa dan kosa kata dalam berbagai jenis teks yang diajarkan yang meliputi. } \\
\text { 1.Penggunaan bunyi bahasa dan pelafalan. } \\
\text { 2. Penggunaan ganti orang. } \\
\text { 3. Penggunaan struktur frasa benda (DM). } \\
\text { 4. Penggunaan kata bilangan tingkat. } \\
\text { 5. Penggunaan kata negasi. } \\
\text { 6. Penggunaan kalimat sederhana. } \\
\text { 7. Penggunaan kata tanya. } \\
\text { 8. Penggunaan kata ganti tunjuk. } \\
\text { 9. Penggunaan posisi dan lokasi. } \\
\text { 10. Penggunaan posisi dan Lokasi. } \\
\text { 11. Penggunaan kata depan. } \\
\text { 12. Penggunaan kata kerja berimbuhan. } \\
\text { 13. Penggunaan kata keterangan. } \\
\text { 14. Penggunaan kata hubung. } \\
\text { 15. Penggunaan ungkapan dan kata sapaan, dan } \\
\text { 16. Penggunaan kosa kata yang berhubungan dengan topik umum. }\end{array}$ \\
\hline
\end{tabular}

Tabel 2. Parameter Deskripsi Capaian Pembelajaran Khusus Bidang Bahasa Indonesia Bagi Penutur Asing (BIPA) Level II

PARAMETER DESKRIPSI CAPAIAN PEMBELAJARAN KHUSUS BIDANG BAHASA INDONESIA BAGI PENUTUR ASING (BIPA) LEVEL II

\begin{tabular}{|c|c|}
\hline SIKAP DAN TATA NILAI & $\begin{array}{l}\text { Membangun dan membentuk karakter dan kepribadian manusia yang. } \\
\text { 1. Bertakwa kepada Tuhan Yang Maha Esa. } \\
\text { 2. Memiliki moral, etika hidup berkelanjutan dan kepribadian yang baik di dalam menyelesaikan } \\
\text { tugasnya. } \\
\text { 3. Berperan sebagai warga negara yang bangga dan cinta tanah air serta mendukung perdamaian dunia. } \\
\text { 4. Mampu bekerja sama dan memiliki kepekaan sosial dan kepedulian yang tinggi terhadap masyarakat } \\
\text { dan lingkungan hidupnya. } \\
\text { 5. Menghargai keanekaragaman budaya, pandangan, kepercayaan, dan agama serta pendapat/temuan } \\
\text { 6. Menjunjung tinggi penegakan hukum serta memiliki semangat untuk mendahulukan kepentingan } \\
\text { 7. Mangsa serta masyarakat luas, dan }\end{array}$ \\
\hline $\begin{array}{ll}\text { KEMAMPUAN } & \text { DI } \\
\text { BIDANG KERJA } & \\
\end{array}$ & $\begin{array}{l}\text { Mengungkapkan perasaan secara sederhana, mendeskripsikan lingkungan sekitar, dan } \\
\text { mengomunikasikan kebutuhan sehari-hari dan rutin. }\end{array}$ \\
\hline $\begin{array}{l}\text { PENGETAHUAN YANG } \\
\text { DIKUASAI }\end{array}$ & $\begin{array}{l}\text { Menguasai penggunaan tata bahasa dan kosa kata dalam berbagai jenis teks yang diajarkan yang } \\
\text { meliputi. } \\
\text { 1. Penggunaan kata negasi. } \\
\text { 2. Penggunaan kata tanya. } \\
\text { 3. Penggunaan kata sifat. } \\
\text { 4. Pengggunaan kata ulang. } \\
\text { 5. Penggunaan perbandingan. } \\
\text { 6. Penggunaan jenis-jenis kalimat. } \\
\text { 7. Penggunaan kata hubung, kata depan, dan kata keterangan. } \\
\text { 8. Penggunaan imbuhan. } \\
\text { 9. Penggunaan kata penggolong. } \\
\text { 10. Penggunaan kata seru, dan } \\
\text { 11. Penggunaan kosa kata yang berhubungan dengan topik tertentu. }\end{array}$ \\
\hline $\begin{array}{l}\text { HAK DAN TANGGUNG } \\
\text { JAWAB }\end{array}$ & $\begin{array}{l}\text { Memiliki hak dan tanggung jawab sebagai berikut. } \\
\text { 1. Bertanggung jawab terhadap penggunaan bahasa Indonesia yang baik dan benar. } \\
\text { 2. Berhak memperoleh pembelajaran bahasa yang sesuai dengan standar yang ditetapkan. }\end{array}$ \\
\hline
\end{tabular}

Tabel 3. Parameter Deskripsi Capaian Pembelajaran Khusus Bidang Bahasa Indonesia Bagi Penutur Asing (BIPA) Level III 


\begin{tabular}{|c|c|}
\hline \multicolumn{2}{|c|}{$\begin{array}{l}\text { PARAMETER DESKRIPSI CAPAIAN PEMBELAJARAN KHUSUS BIDANG BAHASA INDONESIA BAGI } \\
\text { PENUTUR ASING (BIPA) LEVEL III }\end{array}$} \\
\hline $\begin{array}{l}\text { SIKAP } \text { DAN } \\
\text { TATA NILAI }\end{array}$ & $\begin{array}{l}\text { Membangun dan membentuk karakter dan kepribadian manusia yang } \\
\text { 1. Bertakwa kepada Tuhan Yang Maha Esa. } \\
\text { 2. Memiliki moral, etika hidup berkelanjutan dan kepribadian yang baik di dalam menyelesaikan } \\
\text { tugasnya. } \\
\text { 3. Berperan sebagai warga negara yang bangga dan cinta tanah air serta mendukung perdamaian dunia. } \\
\text { 4. Mampu bekerja sama dan memiliki kepekaan sosial dan kepedulian yang tinggi terhadap masyarakat } \\
\text { dan lingkungan hidupnya. } \\
\text { 5. Menghargai keanekaragaman budaya, pandangan, kepercayaan, dan agama serta pendapat/temuan } \\
\text { original orang lain. } \\
\text { 6. Menjunjung tinggi penegakan hukum serta memiliki semangat untuk mendahulukan kepentingan } \\
\text { 7. Memba serta masyarakat luas, dan }\end{array}$ \\
\hline $\begin{array}{l}\text { KEMAMPUAN } \\
\text { DI BIDANG KERJA }\end{array}$ & $\begin{array}{l}\text { Mengungkapkan pengalaman, harapan, tujuan, dan rencana secara singkat dan koheren dengan } \\
\text { disertai alasan dalam konteks kehidupan dan tugas kerja sehari-hari. }\end{array}$ \\
\hline $\begin{array}{l}\text { PENGETAHUAN } \\
\text { YANG DIKUASAI }\end{array}$ & $\begin{array}{l}\text { Menguasai penggunaan tata bahasa dan kosa kata dalam berbagai jenis teks yang diajarkan yang } \\
\text { meliputi. } \\
\text { 1. Penggunaan kata hubung dan partikel. } \\
\text { 2. Penggunaan kata ulang. } \\
\text { 3. Penggunaan kalimat. } \\
\text { 4. Penggunaan imbuhan, dan } \\
\text { 5. Penggunaan kosa kata yang berhubungan dengan situasi/topik/bidang tertentu. }\end{array}$ \\
\hline $\begin{array}{l}\text { HAK } \\
\text { TANGGUNG JAWAB }\end{array}$ & $\begin{array}{l}\text { Memiliki hak dan tanggung jawab sebagai berikut. } \\
\text { 1. } \\
\text { 2. } \\
\text { Bertanggung jawab terhadap penggunaan bahasa Indonesia yang baik dan benar. } \\
\text {. }\end{array}$ \\
\hline
\end{tabular}

Tabel 4. Parameter Deskripsi Capaian Pembelajaran Khusus Bidang Bahasa Indonesia Bagi Penutur Asing (BIPA) Level IV

PARAMETER DESKRIPSI CAPAIAN PEMBELAJARAN KHUSUS BIDANG BAHASA INDONESIA BAGI PENUTUR ASING (BIPA) LEVEL IV

\begin{tabular}{|c|c|}
\hline $\begin{array}{l}\text { SIKAP DAN TATA } \\
\text { NILAI }\end{array}$ & $\begin{array}{l}\text { Membangun dan membentuk karakter dan kepribadian manusia yang } \\
\text { 1. Bertakwa kepada Tuhan Yang Maha Esa. } \\
\text { 2. Memiliki moral, etika hidup berkelanjutan dan kepribadian yang baik di dalam menyelesaikan tugasnya. } \\
\text { 3. Berperan sebagai warga negara yang bangga dan cinta tanah air serta mendukung perdamaian dunia. } \\
\text { 4. Mampu bekerja sama dan memiliki kepekaan sosial dan kepedulian yang tinggi terhadap masyarakat dan } \\
\text { 5. Menghargai keanekaragaman budaya, pandangan, kepercayaan, dan agama serta pendapat/temuan } \\
\text { original orang lain. } \\
\text { 6. Menjunjung tinggi penegakan hukum serta memiliki semangat untuk mendahulukan kepentingan bangsa } \\
\text { 7. Merta masyarakat luas, dan }\end{array}$ \\
\hline $\begin{array}{l}\text { KEMAMPUAN DI } \\
\text { BIDANG KERJA }\end{array}$ & $\begin{array}{l}\text { Melaporkan hasil pengamatan atas peristiwa dan mengungkapkan gagasan dalam topik bidangnya, baik konkret } \\
\text { maupun abstrak, dengan cukup lancar tanpa kendala yang mengganggu pemahaman mitra tutur. }\end{array}$ \\
\hline $\begin{array}{l}\text { PENGETAHUAN } \\
\text { YANG DIKUASAI }\end{array}$ & $\begin{array}{l}\text { Menguasai penggunaan tata bahasa dan kosa kata dalam berbagai jenis teks yang diajarkan yang meliputi. } \\
\text { 1. Penggunaan struktur frasa kompleks. } \\
\text { 2. Penggunaan jenis-jenis kalimat. } \\
\text { 3. Penggunaan imbuhan. } \\
\text { 4. Penggunaan kata hubung. } \\
\text { 5. Penggunaan kata ulang, dan } \\
\text { 6. Penggunaan kosa kata yang berkaitan dengan topik/bidang tertentu. }\end{array}$ \\
\hline $\begin{array}{l}\text { HAK DAN TANGGUNG } \\
\text { JAWAB }\end{array}$ & $\begin{array}{l}\text { Memiliki hak dan tanggung jawab sebagai berikut. } \\
\text { 1. } \quad \text { Bertanggung jawab terhadap penggunaan bahasa Indonesia yang baik dan benar. } \\
\text { 2. } \quad \text { Berhak memperoleh pembelajaran bahasa yang sesuai dengan standar yang ditetapkan. }\end{array}$ \\
\hline
\end{tabular}

Tabel 5. Parameter Deskripsi Capaian Pembelajaran Khusus Bidang Bahasa Indonesia Bagi Penutur Asing (BIPA) Level V

PARAMETER DESKRIPSI CAPAIAN PEMBELAJARAN KHUSUS BIDANG BAHASA INDONESIA BAGI PENUTUR ASING (BIPA) LEVEL V 


\begin{tabular}{|c|c|}
\hline SIKAP DAN TATA NILAI & $\begin{array}{l}\text { Membangun dan membentuk karakter dan kepribadian manusia yang } \\
\text { 1. Bertakwa kepada Tuhan Yang Maha Esa. } \\
\text { 2. Memiliki moral, etika hidup berkelanjutan dan kepribadian yang baik di dalam menyelesaikan } \\
\text { tugasnya. } \\
\text { 3. Berperan sebagai warga negara yang bangga dan cinta tanah air serta mendukung perdamaian dunia. } \\
\text { 4. Mampu bekerja sama dan memiliki kepekaan sosial dan kepedulian yang tinggi terhadap masyarakat } \\
\text { dan lingkungan hidupnya. } \\
\text { 5. Menghargai keanekaragaman budaya, pandangan, kepercayaan, dan agama serta pendapat/temuan } \\
\text { original orang lain. } \\
\text { 6. Menjunjung tinggi penegakan hukum serta memiliki semangat untuk mendahulukan kepentingan } \\
\text { bangsa serta masyarakat luas, dan } \\
\text { 7. Memberikan pelayanan prima diukur dari tingkat kepuasan pemberi tugas. }\end{array}$ \\
\hline $\begin{array}{l}\text { KEMAMPUAN DI } \\
\text { BIDANG KERJA }\end{array}$ & $\begin{array}{l}\text { Memahami teks yang panjang dan rumit serta mampu mengungkapkan gagasan dengan sudut pandang dalam } \\
\text { topik yang beragam secara spontan dan lancar hampir tanpa kendala, kecuali dalam bidang keprofesian dan } \\
\text { akademik. }\end{array}$ \\
\hline $\begin{array}{l}\text { PENGETAHUAN YANG } \\
\text { DIKUASAI }\end{array}$ & $\begin{array}{l}\text { Menguasai penggunaan tata bahasa dan kosa kata dalam berbagai jenis teks yang diajarkan yang meliputi. } \\
\text { 1. } \\
\text { 2. Penggunaan kalimat. } \\
\text { 3. Penggunaan kata hubung dan kata depan. } \\
\text { 4. Penggunaan imbuhan. } \\
\text { 5. Penggunaan ragam formal dan nonformal, dan } \\
\end{array}$ \\
\hline $\begin{array}{l}\text { HAK DAN TANGGUNG } \\
\text { JAWAB }\end{array}$ & $\begin{array}{l}\text { Memiliki hak dan tanggung jawab sebagai berikut. } \\
\text { 1. } \quad \text { Bertanggung jawab terhadap penggunaan bahasa Indonesia yang baik dan benar. } \\
\text { 2. } \quad \text { Berhak memperoleh pembelajaran bahasa yang sesuai dengan standar yang ditetapkan. }\end{array}$ \\
\hline
\end{tabular}

Proses pembelajaran bahasa Indonesia untuk penutur asing (BIPA) dilakukan dalam upayanya untuk meningkatkan empat kompetensi berbahasa, yaitu menyimak, berbicara, membaca, dan menulis. Berdasarkan laporan BIPA pada rentang waktu tahun 2016 sampai dengan 2017, dapat diketahui bahwa hanya tiga belas pengajar dari lima negara yang diketahui telah berhasil meningkatkan empat kompetensi berbahasa secara lengkap kepada para pemelajarnya, yaitu pengajar BIPA yang telah dikirimkan ke Thailand, Vietnam, Myanmar, Perancis, dan Rusia. Hal tersebut dapat dibuktikan dari hasil karya dan nilai capaian pemelajar yang dilampirkan pada laporan pelaksanaan program BIPA.

Kemampuan menulis adalah kemampuan yang paling banyak diajarkan oleh para pengajar BIPA di hampir semua negara tempat mereka bertugas. Terdata sebanyak 22 negara yang menunjukkan peningkatan kemampuan menulis menggunakan bahasa Indonesia yang diajarkan oleh 77 orang pengajar BIPA. Hal tersebut dilatarbelakangi oleh proses pembelajaran yang lebih didominasi oleh kegiatan menulis. Pemelajar BIPA rata-rata mampu menulis kalimat pendek, karangan singkat dengan tema perkenalan atau anggota keluarga, menulis surat pribadi dengan tema sehari-hari, dan surat lamaran pekerjaan. Selain itu, kemampuan membaca dan berbicara merupakan kemampuan yang juga diajarkan dan rata-rata sudah dikuasai oleh pemelajar namun tidak sebanyak kemampuan menulis.

Berbeda dengan kemampuan menulis yang banyak dikuasai pemelajar BIPA, kemampuan menyimak adalah kemampuan yang paling jarang dikuasai oleh pemelajar. Terbukti hanya 15 pengajar yang ditugaskan di tujuh negara yang mampu melaksanakan kegiatan menyimak bagi para pemelajarnya dan mengupayakan adanya peningkatan kemampuan pemelajar dalam memahami rekaman dialog singkat, menginterpretasikan lagu, maupun menyimak video.

Rendahnya kemampuan menyimak ini lebih dikarenakan sebagian besar negara tidak memfasilitasi kelasnya dengan perangkat elektronik, seperti tape recorder, speaker, pemutar video, dan lain-lain. Selain itu, faktor lain yang penghambat kegiatan menyimak adalah terbatasnya kemampuan guru dalam menyediakan sumber-sumber pembelajaran yang dapat disajikan agar kegiatan menyimak menjadi kegiatan yang menarik bagi pemelajar. 
Tabel 6. Hasil Pembelajaran BIPA

\begin{tabular}{|c|c|c|c|c|}
\hline Negara & Menyimak & Berbicara & Membaca & Menulis \\
\hline Singapura & 1 & 1 & 0 & 1 \\
\hline Malaysia & 0 & 0 & 0 & 4 \\
\hline Vietnam & 2 & 2 & 2 & 2 \\
\hline Myanmar & 2 & 2 & 1 & 2 \\
\hline Laos & 0 & 1 & 0 & 2 \\
\hline Thailand & 4 & 7 & 4 & 10 \\
\hline Filipina & 0 & 0 & 0 & 6 \\
\hline Kamboja & 0 & 0 & 0 & 1 \\
\hline Timor Leste & 0 & 0 & 1 & 10 \\
\hline India & 0 & 0 & 0 & 2 \\
\hline Uzbekistan & 0 & 0 & 0 & 2 \\
\hline Jepang & 1 & 0 & 0 & 1 \\
\hline Papua Nugini & 0 & 0 & 4 & 4 \\
\hline Australia & 0 & 0 & 0 & 6 \\
\hline Tunisia & 0 & 1 & 0 & 5 \\
\hline Mesir & 0 & 2 & 2 & 7 \\
\hline Italia & 0 & 0 & 0 & 2 \\
\hline Finlandia & 0 & 0 & 0 & 1 \\
\hline Jerman & 0 & 0 & 0 & 1 \\
\hline Inggris & 0 & 0 & 2 & 0 \\
\hline Rusia & 2 & 3 & 3 & 2 \\
\hline Perancis & 3 & 4 & 5 & 3 \\
\hline Amerika Serikat & 0 & 0 & 0 & 4 \\
\hline
\end{tabular}

Pada tabel di atas dapat diketahui bahwa diantara empat kemampuan berbahasa, kemampuan menyimak menunjukkan hasil belajar yang paling rendah. Hal tersebut dikarenakan para pengajar BIPA jarang mengajarkan kemampuan tersebut dan jarang melakukan aktifitas mendengar. Dari tabel tersebut dapat diketahuipula pemetaan pencapaian kompetensi pembelajaran BIPA di semua negara sasaran, seperti tampak pada infografis berikut ini.

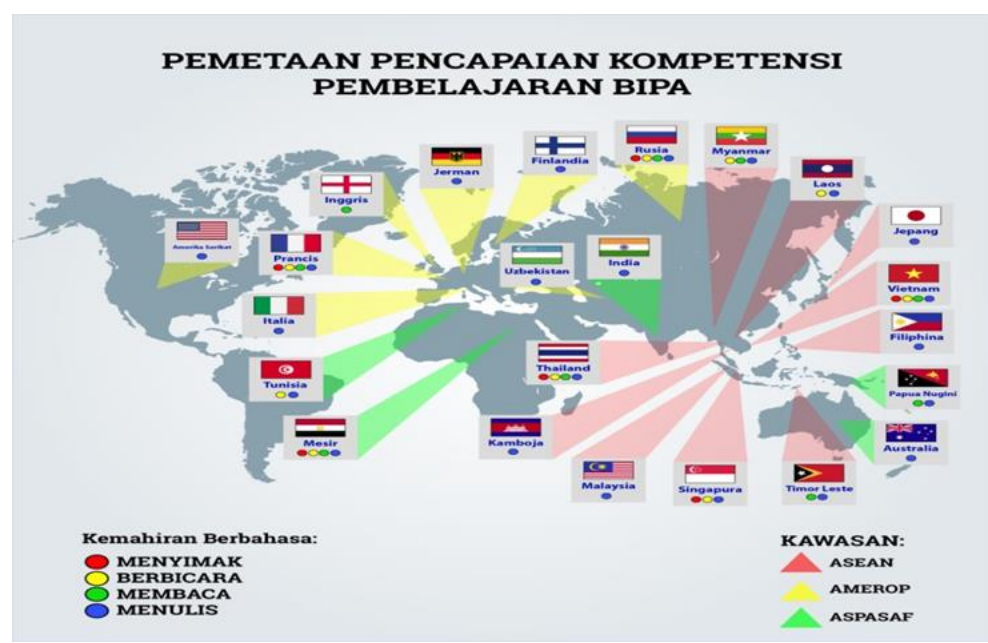

Gambar 1. Pemetaan Pencapaian Kompetensi Pembelajaran BIPA 
Rendahnya kemampuan menyimak juga terlihat dari hasil kuisioner yang diberikan pada guru-guru BIPA. Sebanyak 12 dari 42 guru BIPA menyatakan bahwa pemelajar di kelas mereka tidak mampu menyimal audio dalam bahasa Indonesia sesuai dengan level dan materi yang diajarkan. Rendahnya kemampuan menyimak pemelajar BIPA tersebut didominasi oleh Negara Timor Leste, Thailand, Vietnam, Kamboja, Uzbekistan, dan Perancis.

Tolak ukur keberhasilan pembelajaran BIPA adalah kesesuaian antara hasil pembelajaran dengan Standar Kompetensi Lulusan sesuai yang tercantum pada Permendikbud Nomor 5 Tahun 2016. Dari keseluruhan laporan guru BIPA dari rentang tahun 2016 sampai dengan 2017 yang telah dianalisis, negaranegara yang memiliki kesesuaian hasil pembelajaran dengan Standar Kompetensi Lulusan telah diuraikan di dalam tabel berikut.

Tabel 7. Kesesuaian Hasil Pembelajaran dengan Standar Kompetensi Lulusan

\begin{tabular}{|c|c|c|c|}
\hline Negara & Sesuai & Cukup Sesuai & Kurang Sesuai \\
\hline Singapura & 1 & 0 & 0 \\
\hline Malaysia & 4 & 0 & 0 \\
\hline Vietnam & 2 & 0 & 0 \\
\hline Myanmar & 2 & 0 & 0 \\
\hline Laos & 1 & 1 & 0 \\
\hline Thailand & 13 & 2 & 4 \\
\hline Filipina & 5 & 0 & 1 \\
\hline Kamboja & 1 & 0 & 0 \\
\hline Timor Leste & 6 & 0 & 4 \\
\hline India & 2 & 0 & 0 \\
\hline Uzbekistan & 2 & 0 & 0 \\
\hline Jepang & 1 & 0 & 0 \\
\hline Papua Nugini & 4 & 0 & 0 \\
\hline Australia & 6 & 0 & 0 \\
\hline Tunisia & 4 & 0 & 1 \\
\hline Mesir & 7 & 0 & 0 \\
\hline Italia & 2 & 0 & 0 \\
\hline Finlandia & 1 & 0 & 0 \\
\hline Jerman & 0 & 1 & 0 \\
\hline Inggris & 2 & 0 & 0 \\
\hline Rusia & 3 & 0 & 0 \\
\hline Perancis & 5 & 0 & 0 \\
\hline Amerika Serikat & 3 & 0 & 1 \\
\hline
\end{tabular}

Berdasarkan data hasil laporan program BIPA sepanjang tahun 2016 dan 2017 dan data hasil kuisioner dapat disimpulkan bahwa program BIPA telah berhasil mengajarkan bahasa Indonesia kepada pemelajar asing sesuai dengan SKL. Namun masih memerlukan perhatian khusus terhadap penyampaikan materi oleh guru dan alat ukur pembelajaran, terutama instrumen test yang diberikan oleh siswa.

Namun perlu diperhatikan, bahwa instrumen test yang dibuat oleh pengajar harus sesuai dengan materi yang diajarkan selama di kelas. Hasil kuisioner menyatakan bahwa materi yang diajarkan terlalu 
banyak sehingga pemelajar kesulitan menyerap materi dan menjawab soal. Oleh karena itu, setiap materi yang diajarkan harus dipastikan terukur dengan waktu dan target pembelajaran, sehingga materi tersebut terserap dan dipahami oleh pemelajar, mampu dipraktikkan baik dalam dalam kehidupan sehari-hari dan pada saat mengerjakan test bahasa Indonesia.

\section{Simpulan}

Pembelajaran bahasa Indonesia bagi penutur asing dilaksanakan oleh PPSDK bekerja sama dengan negara-negara penyelenggara BIPA. Rata-rata pengajar BIPA yang telah dikirimkan PPSDK ke 23 negara penyelenggara BIPA telah mampu mengajarkan bahasa Indonesia pada level dasar A1 atau A2. Hanya sedikit lembaga sasaran yang menyelenggarakan pembelajaran level menengah B1 dan B2 dan level mahir $\mathrm{C} 1$ dan $\mathrm{C} 2$ dengan jumlah peserta yang masih sedikit.

Hasil pembelajaran BIPA yang telah dilaksanakan dari rentang waktu 2016 sampai dengan 2017 menunjukkan bahwa kemampuan menyimak pemelajar BIPA telah dikuasai siswa di lima belas sekolah penyelenggara BIPA dengan persentase 10,6\%. Kemampuan berbicara pemelajar BIPA telah dikuasai siswa di 23 sekolah penyelenggara BIPA dengan persentase 16, 3\%. Kemampuan membaca pemelajar BIPA telah dikuasai siswa di 24 sekolah penyelenggara BIPA dengan persentase $17,1 \%$. Kemampuan menulis pemelajar BIPA telah dikuasai siswa di 79 sekolah penyelenggara BIPA dengan persentase sebanyak $56,1 \%$.

\section{Ucapan Terima Kasih}

Terima kasih penulis ucapkan kepada Prof. Emi Emilia, Ph.D. M.Ed. selaku Kepala PPSDK yang telah memberikan arahannya dalam proses penulisan artikel ini. Terima kasih juga kepada semua pihak yang telah membantu dalam proses penulisan artikel ini.

\section{Daftar Rujukan}

Badan Pengembangan dan Pembinaan Bahasa. Diakses dari badanbahasa.kemdikbud.go.id

Emilia, Emi. (2009). Menulis Tesis dan Disertasi. Bandung: Alfabeta.

Permendikbud Nomor 27 Tahun 2017 tentang Standar Kompetensi Lulusan (SKL) BIPA.

Undang-Undang Nomor 24 Tahun 2009 tentang Bendera, Bahasa, dan Lambang Negara serta Lagu Kebangsaan.

Peraturan Presiden Nomor 8 Tahun 2012 tentang Kerangka Kualifikasi Nasional Indonesia (KKNI).

Peraturan Pemerintah Nomor 57 Tahun 2014 tentang Pengembangan, Pembinaan, dan Pelindungan Bahasa dan Sastra, serta Peningkatan Fungsi Bahasa Indonesia

Peraturan Pemerintah Nomor 13 Tahun 2015 tentang Perubahan Kedua atas Standar Nasional Pendidikan

Peraturan Pemerintah Nomor 19 Tahun 2005 tentang Standar Nasional Pendidikan (SNP)

Permendikbud Nomor 131 Tahun 2014 tentang Standar Kompetensi Lulusan (SKL) Kursus dan Pelatihan.

Permendikbud Nomor 5 Tahun 2015 tentang kriteria lulusan peserta didik, penyelenggaraan ujian nasional, dan penyelenggaraan ujian sekolah/madrasah/pendidikan kesetaraan pada SMP/MTs atau yang sederajat dan SMA/MA/SMK atau yang sederajat. 
Permendikbud Nomor 27 Tahun 2017 Tentang Standar Kompetensi Lulusan Kursus dan Pelatihan Bidang Keterampilan Kepemanduan Wisata, Pemeliharaan Taman, Pekarya Kesehatan, Petukangan Kayu Konstruksi, Pemasangan Bata, Perancah, Pemasangan Pipa, Mekanik Alat Berat, Bahasa Indonesia Bagi Penutur Asing, Pembuatan Batik Dengan Pewarna Ramah Lingkungan, Pembuatan Malam Batik, Pembuatan Batik Dengan Pewarna Sintetis, Pembuatan Alat Canting Tulis, dan Pembuatan Canting Cap.

Sumaryono, E. (1999). Hermeneutik, Sebuah Metode Filsafat. Yogyakarta: Kanisius.

Badan Pengembangan dan Pembinaan Bahasa. 2018. Jaringan Lembaga Penyelenggara BIPA. (http://bipa.kemdikbud.go.id/jaga) 